Annals of Plant and Soil Research 23(2): 223-227 (2021)

https://doi.org/10.47815/apsr.2021.10062

\title{
Effect of organic manures as INM component on growth and yield of chilli (Capsicum annuum L.)
}

\author{
SAKTHIVEL. B AND K. MANIVANNAN
}

\author{
Department of Horticulture, Faculty of Agriculture, Annamalai University, Annamalai Nagar, Chidambaram- \\ 608002, Tamil Nadu, India
}

Received: February, 2021; Revised accepted: March, 2021

\begin{abstract}
A field experiment was conducted during rabi season of 2019 at farmer's field in Panruti near Cuddalore district (Tamil Nadu) to study effect of organic manures as INM component on growth, yield and quality of chilli (Capsicum annuum L.) in a randomized block design. The treatments consisted of recommended dose of fertilizers at two levels (160:60:30 and 120:45:22.5 $\mathrm{kg} \mathrm{NPK} \mathrm{ha}^{-1}$ ) and organic manures (20 t FYM ha ${ }^{-1}, 50 \mathrm{~kg} \mathrm{Bio}^{-1}$ ash ha ${ }^{-1}, 5 t$ press mud granules ha ${ }^{-1}, 20 \mathrm{~kg}$ Sea weed extract granules ha $\mathrm{h}^{-1}$ and $5 \mathrm{t}$ neem cake ha $\mathrm{c}^{-1}$ ) and replicated three times. The growth and yield parameters of chilli were significantly influenced due to application of organic manures. Among the treatments, $75 \% R D F+20 t F Y M+20 \mathrm{~kg}$ Sea weed extract granules $+5 t$ neem cake ha ${ }^{-1}\left(T_{8}\right)$ exhibited better performances of growth and yield parameters of chilli cv. Indus 13 . The maximum values of growth parameters such as plant height, leaves plant ${ }^{-1}$, branches plant ${ }^{-1}$, canopy volume, chlorophyll content in the leaves and net photosynthetic rate were observed in this treatment $\left(T_{8}\right)$. The yield parameters such as days to first flowering, days to $50 \%$ flowering, flowers plant ${ }^{-1}$, fruit set, fruits plant ${ }^{-1}$, fruit length, fruit girth, pericarp thickness, pulp seed ratio, single fruit weight, total fruit yield (28.18 $t$ ha $\left.^{-1}\right)$ and quality parameters like capsaicin content (0.76\%) and ascorbic acid content $\left(171.3 \mathrm{mg} \mathrm{\textrm {g } ^ { - 1 } )}\right.$ were highest in this treatment $\left(T_{8}\right)$ suggested this is the best integrated nutrient management combination for chilli. Application of $100 \% \operatorname{RDF}\left(160: 30: 30 \mathrm{~kg} \mathrm{ha}^{-1}\right)$ proved inferior in respect of growth and yield of chilli.
\end{abstract}

Key words: Organic manure, chilli, INM, organic manures, yield

\section{INTRODUCTION}

Chillies, green or red fruits of Capsicum annuum $\mathrm{L}$. belong to the family Solanaceae and originate from South America. Chilli is rich sources of vitamins $A, C, E$ and $P$. Hundred gram of edible portions of capsicum provides 24 $\mathrm{k}$ cal of energy, $1.3 \mathrm{~g}$ of protein, $4.3 \mathrm{~g}$ of carbohydrate and $0.3 \mathrm{~g}$ of fat (Chakrabarty et al., 2017). The fresh green and ripe chilli fruits are used to make all kinds of pickles, different sauces and paste. It is an integral ingredients in most cuisines around the world but also adds pungency, taste, flavor and color to the dishes and hence named as 'wonder spice'. India is the largest producer, consumer as well as exporter of chilli, which contribute to $25 \%$ of the total world's production. In India, the area under chilli is about 422 thousand hectares and production 4097 thousand MT with productivity of 1.9 thousand MT per hectare during the year 201920 (Anon, 2020). Nowadays, chilli crop is normally grown as mono crop following all modern good horticulture practices. The deficiency in plant nutrients causes different changes in the physiological and biochemical processes within the plant cell resulting a delay in development and reduction in growth as well as yield.Integrated nutrient management system aims at maintenance of soil fertility and plant nutrient supply to an optimum level for sustaining the desired crop productivity through optimization of benefits to all possible sources of plant nutrients in an integrated manner (Koshale et al., 2018). The nutrients like $\mathrm{N}, \mathrm{P}$ and $\mathrm{K}$ supply through chemical fertilizers have played significant role on increasing the yield and quality in the plants. But also usage of chemical fertilizers indiscriminately in an unbalanced manner has been shown to result in several problems like poor soil health, multiple nutrient deficiencies and loss of microbial activities etc, which results ultimately to reduced crop productivity and fruit quality. Use of organic manures to meet the nutrient requirements of crop would be an inevitable practice in the years to come for suitable horticulture since the organic manures not only improve the physical, chemical and biological properties of soil. Organic manures like farmyard manures, bio 
ash, press mud granules, seaweed extract granules, neem cake and crop residues are considered as a store house of various nutrients which are essential for the plant growth. Use of organic manures alone cannot fulfill the crops nutrient requirement. The combination of organic manures and inorganic fertilizers gave the better results than organic manures alone (Kapse et al., 2017). The integrated supply and use of plant nutrients from chemical fertilizers and organic manures has shown to produce higher fruit yield than when they are applied alone. The present study was conducted with the objective to study the effect of individual and combined application of organics on growth, yield and biochemical parameters of chilli.

\section{MATERIALS AND METHODS}

The experiment was conducted in a randomized block design with three replications during rabi season of 2019 in farmer's field at Panruti village in Tamil Nadu. The experiment comprised 10 treatments viz., $\mathrm{T}_{1}-100 \%$ RDF (160:60:30 kg NPK ha $\left.{ }^{-1}\right), \mathrm{T}_{2}-75 \%$ RDF $\left(120: 45: 22.2 \mathrm{~kg} \mathrm{NPK} \mathrm{ha}^{-1}\right)+20 \mathrm{t} \mathrm{FYM} \mathrm{ha}^{-1}, \mathrm{~T}_{3}-$ $75 \%$ RDF $+50 \mathrm{~kg}$ bio ash ha-1, $\mathrm{T}_{4}-75 \%$ RDF $+20 \mathrm{~kg}$ press mud granules ha ${ }^{-1}, \mathrm{~T}_{5}-75 \%$ RDF $+20 \mathrm{t} \mathrm{FYM}+20 \mathrm{~kg}$ sea weed extract granules $\mathrm{ha}^{-1}, \mathrm{~T}_{6}-75 \%$ RDF $+50 \mathrm{~kg}$ bio ash $+20 \mathrm{~kg}$ sea weed extract granules ha ${ }^{-1}, \mathrm{~T}_{7}-75 \%$ RDF $+20 \mathrm{~kg}$ press mud granules $+20 \mathrm{~kg}$ sea weed extract granules, $\mathrm{T}_{8}-75 \% \mathrm{RDF}+20 \mathrm{t} \mathrm{FYM}+$ $20 \mathrm{~kg}$ sea weed extract granules $+5 \mathrm{t}$ neem cake ha ${ }^{-1}, \mathrm{~T}_{9}-75 \%$ RDF $+50 \mathrm{~kg}$ bio ash +20 $\mathrm{kg}$ sea weed extract granules $+5 \mathrm{t}$ Neem cake $\mathrm{ha}^{-1}, \quad \mathrm{~T}_{10}-75 \%$ RDF $+20 \mathrm{~kg}$ press mud granules $+20 \mathrm{~kg}$ sea weed extract granules $+5 \mathrm{t}$ neem cake ha-1 ${ }^{-1}$. Chilli seeds of the variety Indus 13 was raised in portray nursery. The plants were transplanted 45 days after sowing. The planting sowing 45 days after transplanting in portray. The seedlings were planted in bed width/length measuring $(0.8$ to $25 \mathrm{~m})$ with spacing of $1 \mathrm{~m}$ (row to row) $\times 0.45 \mathrm{~cm}$ (plant to plant). Matured green fruits were harvested from the plant in phases up to the drying of the plants. Other cultural practices except manure were followed as per crop production manual suggested by TNAU portal. The nutrients were applied as per treatment schedule. Observations were recorded on different growth, flowering, yield and quality parameters and analyzed statistically (Gomez and Gomez, 1984). Capsaicin and ascorbic acid content of chilli were estimated following the standard biochemical method (Sadasivam and Manickam, 1996)

\section{RESULTS AND DISCUSSION}

\section{Growth parameters}

The highest growth in terms of plant height $(124.8 \mathrm{~cm})$, leaves plant $^{-1}$ (399.5), branches plant $^{-1}$ (136.8), canopy volume (198.6 $\mathrm{cm}^{3}$ ), chlorophyll content in the leaves $(9.54 \mathrm{mg}$ $\left.\mathrm{g}^{-1}\right)$ and net photosynthetic rate (84.7) were recorded with $75 \% \mathrm{RDF}+20 \mathrm{tFYM}+20 \mathrm{~kg}$ sea weed extract granules $+5 \mathrm{t}$ neem cake ha-1 (Table 1). However, the next best treatment was $75 \%$ RDF $+50 \mathrm{~kg}$ bio ash $+20 \mathrm{~kg}$ sea weed extract granules $+5 \mathrm{t}$ neem cake $\mathrm{ha}^{-1}$ in respect of these growth characters. All the growth parameters were recorded lowest with the RDF (160:60:30 kg NPK ha ${ }^{-1}$ ). The combination of organic manures and inorganic fertilizer has increased the growth and development processes of the plant which may be due to the increase in the availability of plant nutrients especially nitrogen, the chief nutrient of protein for the formation of protoplasm, cell division, cell enlargement and symbiotic activity which influence play important role in growth of plant (Narute et al., 2020). The best treatment has improved the growth parameters due to higher level of nitrogen and other nutrients from neem cake and FYM which might have acted as additional amount of nutrients and also improve the physico-chemical and microbial environment of the rhizosphere leading to better expression of response (Mishra et al., 2018). The better photosynthetic activity due to sufficient availability of NPK supplemented with FYM helped the plants to attain more vigorous growth which in turn produced plant height more the number of leaves per plant compared to NPK and FYM (Sukhlal et al., 2019). Subhashree et al. (2020) and Prashant (2019). 
Table 1: Effect of organic manures as INM on growth parameters in chilli

\begin{tabular}{|c|c|c|c|c|c|c|c|c|c|}
\hline Treatment & $\begin{array}{c}\text { Plant } \\
\text { height } \\
(\mathrm{cm})\end{array}$ & $\begin{array}{c}\text { Leaves } \\
\text { plant }^{-1}\end{array}$ & $\begin{array}{c}\text { Branches } \\
\text { plant }^{-1}\end{array}$ & $\begin{array}{c}\text { Canopy } \\
\text { volume } \\
\left(\mathrm{cm}^{3}\right)\end{array}$ & $\begin{array}{c}\text { Chlorophyll } \\
\text { content in } \\
\text { the leaves } \\
\left(\mathrm{mg} \mathrm{g}^{-1}\right)\end{array}$ & $\begin{array}{c}\text { Net } \\
\text { photosynthetic } \\
\text { rate } \\
\left(\mu \text { molCO }_{2} \mathrm{~m}^{-2} \mathrm{~s}^{-1}\right)\end{array}$ & $\begin{array}{c}\text { Days to } \\
1^{\text {st }} \\
\text { flowering }^{2}\end{array}$ & $\begin{array}{c}\text { Days to } \\
50 \% \\
\text { flowering }\end{array}$ & $\begin{array}{c}\text { Flowers } \\
\text { plant }\end{array}$ \\
\hline $\mathrm{T}_{1}$ & 116.4 & 336.2 & 114.0 & 165.0 & 6.54 & 64.12 & 41.5 & 58.7 & 60.1 \\
$\mathrm{~T}_{2}$ & 118.4 & 350.2 & 119.0 & 172.4 & 7.25 & 68.46 & 39.9 & 56.5 & 64.2 \\
$\mathrm{~T}_{3}$ & 119.0 & 357.3 & 116.5 & 176.2 & 7.59 & 70.23 & 39.1 & 55.4 & 66.6 \\
$\mathrm{~T}_{4}$ & 117.1 & 343.2 & 127.2 & 168.7 & 6.89 & 66.35 & 40.7 & 57.6 & 62.2 \\
$\mathrm{~T}_{5}$ & 121.4 & 378.4 & 129.1 & 187.2 & 8.61 & 78.32 & 36.8 & 51.9 & 74.6 \\
$\mathrm{~T}_{6}$ & 120.1 & 371.4 & 126.6 & 183.6 & 8.27 & 76.53 & 37.6 & 53.0 & 71.8 \\
$\mathrm{~T}_{7}$ & 119.5 & 364.3 & 124.1 & 180.0 & 7.94 & 74.72 & 38.4 & 54.2 & 68.0 \\
$\mathrm{~T}_{8}$ & 124.8 & 399.5 & 136.8 & 198.6 & 9.54 & 84.77 & 34.5 & 48.4 & 84.6 \\
$\mathrm{~T}_{9}$ & 123.7 & 392.5 & 134.3 & 194.8 & 9.26 & 82.65 & 35.3 & 49.6 & 80.5 \\
$\mathrm{~T}_{10}$ & 122.1 & 385.4 & 131.7 & 190.0 & 8.92 & 80.82 & 36.1 & 50.7 & 77.7 \\
$\mathrm{~S}$. Ed & 2.23 & 6.83 & 2.37 & 3.38 & 0.15 & 1.39 & 0.71 & 1.00 & 1.31 \\
$\mathrm{CD}(\mathrm{p}=0.05)$ & 4.69 & 14.36 & 4.87 & 7.10 & 0.30 & 2.92 & 1.49 & 2.00 & 2.75 \\
$\mathrm{CV} \%$ & 2.27 & 2.27 & 2.28 & 2.27 & 2.41 & 2.28 & 2.40 & 2.33 & 2.26 \\
\hline
\end{tabular}

$T_{1}-100 \%$ RDF (160:60:30 kg NPK ha- $), T_{2}-75 \%$ RDF $\left(120: 45: 22.2 \mathrm{~kg} \mathrm{NPK} \mathrm{ha}^{-1}\right)+20$ t FYM ha- ${ }^{-1}, \mathrm{~T}_{3}-75 \%$ RDF + $50 \mathrm{~kg} \mathrm{Bio}$ Ash ha- ${ }^{-1}, T_{4}-75 \% R D F+20 \mathrm{~kg}$ Press mud granules ha $a^{-1}, T_{5}-75 \% R D F+20 t \mathrm{FYM} \mathrm{ha}^{-1}+20 \mathrm{~kg}$ Sea weed extract granules ha- ${ }^{-1}$, $T_{6}-75 \% R D F+50 \mathrm{~kg}$ Bio Ash ha-1 $+20 \mathrm{~kg}$ Sea weed extract granules ha ${ }^{-1}, T_{7}-75 \% R D F+20 \mathrm{~kg}$ Press mud granules ha ${ }^{-1}+20$ $\mathrm{kg}$ Sea weed extract granules ha- ${ }^{-1}, T_{8}-75 \% R D F+20$ t FYM ha ${ }^{-1}+20 \mathrm{~kg}^{-1}$ Sea weed extract granules ha ${ }^{-1}+5$ t Neem cake ha- ${ }^{-1}$, $T_{9}-75 \% R D F+50 \mathrm{~kg}$ Bio Ash ha ${ }^{-1}+20 \mathrm{~kg}$ Sea weed extract granules ha-1 $+5 t$ Neem cake ha ${ }^{-1}, T_{10}-75 \%$ RDF $+20 \mathrm{~kg}$ Press mud granules ha ${ }^{-1}+20 \mathrm{~kg}$ Sea weed extract granules ha ${ }^{-1}+5 \mathrm{t} \mathrm{Neem} \mathrm{cake} \mathrm{ha}^{-1}$

\section{Yield parameters and Yield}

Significantly early flowering ( 34.5 days to first flowering and 48.4 days to $50 \%$ flowering) was recorded with $75 \%$ RDF +20 t FYM $+20 \mathrm{~kg}$ sea weed extract granules $+5 \mathrm{t}$ neem cake ha- ${ }^{-1}$, followed by $75 \%$ RDF $+50 \mathrm{~kg}$ bio ash $+20 \mathrm{~kg}$ sea weed extract granules $+5 \mathrm{t}$ neem cake ha ${ }^{-1}$, which recorded 35.3 days to first flowering and 49.6 days to $50 \%$ flowering. The flowering was significantly delayed in $100 \%$ RDF with 41.5 days to first flowering and 58.7 days to $50 \%$ flowering and number of flowers plant ${ }^{-1}$ (84.6). The flowering and yield parameters of chilli were also significantly influenced by organic manures, NPK fertilizers and bio ash (Table 2). Among the treatments, the highest yield parameters in terms of fruit set $\%$ (67.6), fruits plant ${ }^{-1}(56.7)$, fruit length $(14.8 \mathrm{~cm})$, fruit girth (3.69), pericarp thickness $(1.19 \mathrm{~mm})$, pulp seed ratio (8.68), single fruit weight $(18.51 \mathrm{~g})$, total fruit yield $\left(28.18 \mathrm{t} \mathrm{ha}^{-1}\right)$ and quality parameters like capsaicin content $(0.76 \%)$ and ascorbic acid content $\left(171.3 \mathrm{mg} \mathrm{g}^{-1}\right)$ were recorded with $75 \%$ RDF +20 t FYM $+20 \mathrm{~kg}$ sea weed extract granules +5 t neem cake ha ${ }^{-1}$. The next best treatment in terms of these parameters was $75 \%$ $\mathrm{RDF}+50 \mathrm{Kg}$ bio ash $+20 \mathrm{Kg}$ sea weed extract granules +5 t neem cake ha ${ }^{-1}$.
All yield parameters were the lowest with $100 \%$ RDF. The uptake of plant nutrients supplied by chemical fertilizer and organic manures were available to plants in sufficient amount throughout the growth period to increase the fruit weight. The results are in accordance with the findings in (Reddy et al., 2017). The yield parameters were recorded higher with combined application of FYM and neem cake which may be due to better root proliferation, more uptakes of nutrients and water, more photosynthesis activity and enhanced food accumulation (Gokul et al., 2020). Moreover, FYM seems to act directly in increasing fruit yields either by accelerating respiratory process by increasing cell permeability, hormone growth action or by combination of all these processes (Hussein et al., 2018). The application of seaweed extract will resonate with the ecosystem of plants growth and development of vigorous root system, increase to cell elongation and more cytokinin synthesis. Furthermore, the increased quality attributes due to organic manures were observed when compared to recommended dose of fertilizers practices in terms of dry chilli fruits. The highest capsaicin content with FYM and neem cake might be due to improved physico-chemical properties of the soil and its soil structure for root growth, thereby improving fruit quality (Subhashree et al., 2020). 
Muhammad et al., (2019) reported that high $\mathrm{N}$ uptake enhanced the enzyme activities for amino acid synthesis and increased ascorbic acid content in green chilli fruits.

Table 2: Effect of bulky organic manures as INM on yield parameters and yield of chilli

\begin{tabular}{|c|c|c|c|c|c|c|c|c|c|c|}
\hline Treatment & $\begin{array}{c}\text { Fruit } \\
\text { set } \\
\%\end{array}$ & $\begin{array}{c}\text { Fruits } \\
\text { plant }^{-1}\end{array}$ & $\begin{array}{c}\text { Fruit } \\
\text { length } \\
(\mathrm{cm})\end{array}$ & $\begin{array}{c}\text { Fruit } \\
\text { girth }\end{array}$ & $\begin{array}{c}\text { Pericarp } \\
\text { thickness } \\
(\mathrm{mm})\end{array}$ & $\begin{array}{c}\text { Pulp: } \\
\text { seed } \\
\text { ratio }\end{array}$ & $\begin{array}{c}\text { Single } \\
\text { fruit } \\
\text { weight }(\mathrm{g})\end{array}$ & $\begin{array}{c}\text { Total fruit } \\
\text { yield } \\
\left(\mathrm{t} \mathrm{ha}{ }^{-1}\right)\end{array}$ & $\begin{array}{c}\text { Capsaicin } \\
\text { content } \\
(\%)\end{array}$ & $\begin{array}{c}\text { Ascorbic } \\
\text { acid content } \\
\left(\mathrm{mg} \mathrm{g}^{-1}\right)\end{array}$ \\
\hline $\mathrm{T}_{1}$ & 51.6 & 31.0 & 11.22 & 2.89 & 0.77 & 5.09 & 9.65 & 17.43 & 0.58 & 152.5 \\
$\mathrm{~T}_{2}$ & 57.7 & 37.0 & 12.12 & 3.06 & 0.85 & 5.72 & 11.42 & 19.53 & 0.62 & 156.3 \\
$\mathrm{~T}_{3}$ & 59.5 & 39.6 & 12.53 & 3.16 & 0.90 & 6.03 & 12.83 & 21.15 & 0.64 & 158.5 \\
$\mathrm{~T}_{4}$ & 55.6 & 34.6 & 11.68 & 2.98 & 0.81 & 5.42 & 10.34 & 18.20 & 0.60 & 154.7 \\
$\mathrm{~T}_{5}$ & 64.5 & 48.1 & 13.71 & 3.41 & 1.04 & 7.39 & 15.78 & 24.35 & 0.70 & 165.6 \\
$\mathrm{~T}_{6}$ & 63.1 & 45.3 & 13.34 & 3.33 & 0.99 & 6.98 & 14.45 & 23.11 & 0.68 & 163.8 \\
$\mathrm{~T}_{7}$ & 61.7 & 42.0 & 12.95 & 3.24 & 0.95 & 6.37 & 13.48 & 22.35 & 0.66 & 160.7 \\
$\mathrm{~T}_{8}$ & 67.6 & 56.7 & 14.88 & 3.69 & 1.19 & 8.68 & 18.51 & 28.18 & 0.76 & 171.3 \\
$\mathrm{~T}_{9}$ & 66.3 & 54.0 & 14.43 & 3.61 & 1.15 & 8.22 & 17.45 & 27.30 & 0.74 & 169.4 \\
$\mathrm{~T}_{10}$ & 65.0 & 50.5 & 14.04 & 3.52 & 1.09 & 7.83 & 16.68 & 25.98 & 0.72 & 167.7 \\
$\mathrm{~S} . \mathrm{Ed}$ & 1.14 & 0.84 & 0.24 & 0.06 & 0.02 & 0.12 & 0.27 & 0.43 & 0.01 & 3.15 \\
$\mathrm{CD}(\mathrm{p}=0.05)$ & 2.41 & 1.77 & 0.51 & 0.12 & 0.04 & 0.26 & 0.57 & 0.91 & 0.02 & 6.30 \\
$\mathrm{CV} \%$ & 2.32 & 2.35 & 2.30 & 2.41 & 2.38 & 2.32 & 2.37 & 2.34 & 2.43 & 2.27 \\
\hline
\end{tabular}

On the basis of the results, it may be concluded that $75 \%$ RDF $+20 \mathrm{t} \mathrm{FYM}+20 \mathrm{~kg}$ Sea weed extract granules $+5 \mathrm{t}$ neem cake ha ${ }^{-1}$ showed better results compared to other treatments in improving the growth and yield of chilli. cv. Indus 13.

\section{REFERENCES}

Anonymous (2020) State Wise Area and Production of Chilli. Horticultural Statistics at a Glance 2019-20: p-194.

Chakrabarty, S., Mominul Islam, A. K and Aminul Islam, A.K.M. (2017) Nutritional benefits and pharmaceutical Potentialities of chilli:

A Review. Fundamental and Applied Agriculture 2 (2): 227-232.

Gokul, D., Poonkodi, P. and Angayarkanni, A. (2020) Effect of integrated nutrient management on the growth and nutrient content of chilli (Capsicum annuum L.). International Journal of Chemical Studies 8 (4): 2647-2651.

Gomez, K. A. and Gomez A. A. (1984) Statistical Procedures in Agricultural Research, Wiley, New York, Chichester, $2^{\text {nd }}$ edition, pp. 680.
Hussein, H.A., Muhanad, W.A. and Ramadan, K.H. (2018) Effect of farm yard manure and NPK on the yield and some growth components of tomato (Lycopersicum esculentum). Research on Crops 19 (4): 655-658.

Kapese, V.D., Puranik, U.Y., Bhosale, A. R., Gokhala, N. B and Kastura, M. C. (2017) Effect of integrated nutrient management on yield of chilli and physic-chemical properties of soil in Konkan region of Maharashra. International Journal of Chemical Studies 5 (2): 106-109.

Koshale, C., Kurrey, D.K and Banjare, L.D. (2018) Effect of organic manure and inorganic fertilizer on growth, yield and physiological parameter of chilli. International Journal of Chemical Studies $6(4): 118-122$. 
Muhammad Ahsan Altaf, Rabia Shahid, Muhammad Asad Altaf, Ming-Xun Ren, Ke Tan, Wen-Qian Xiang, Abdul Qadir, Awais Shakoor and Muhammad Mohsin Altaf. (2019) Effect of NPK, organic manure and their combination on growth, yield and nutrient uptake of chilli (Capsicum annuum L.). Horticulture International Journals 9 (5):217-222.

Narute, R.M., Vaidya, P. H and Shrivastav, A. S. (2020) Effect of tank silt, organic and inorganic fertilizers on growth, nutrients uptake yield and yield attributes of chilli (Capsicum annuum L.) under Inceptisol. The Pharma Innovation Journal 9 (11): 289-294.

Prashant, M.N. (2019) Bio-efficacy of opteineseaweed extract in promoting growth and yield of chilli. Journal of Indian Society Coastal Agriculture Research 37 (1): 9295.

Reddy, G.C., Venkatachalapathi, V., Reddy, G. P.D. and Hebbar, S.S. (2017) Study of different organic manure combination on Growth and yield of chilli. Journal of ISSN 17(1):472-474.

Sadasivam, S. and Manickam, A. (1996) Biochemical Methods ( $2^{\text {nd }}$ edn) New Age
International Publisher, New Delihi, pp. 187-188.

Subhashree Behera, Poonam Preeti Pradhan, Gayatri Sahu and Gour Hari Santra. (2020) Integrated nitrogen management in growth and yield of chilli (Capsicum annuum L.) under red and lateritic soils of Odisha. International Journal of Plant and Soil Science 32 (12): 28-34.

Sukhlal Waskel, Sunil Kumar Jatav and Singh, S. S. (2019) Effect of integrated nutrient management on growth and yield attributes of brinjal. International Journals of Current Microbiology and Applied Sciences 8 (11): 1849-1853.

Vinay Kumar Mishra, V.K., Kumar S. and Vijaya Kumar Pandey, V.K. (2018) Effect of organic manure and bio-fertilizers on growth, yield and quality of brinjal (Solanum melongena L.). International Journal of Pure and Applied Bioscience 6 (1): 704-707. 